\title{
ОСОБЛИВОСТІ ПРОДОВОЛЬЧОГО ЗАБЕЗПЕЧЕННЯ СІЛЬСЬКИХ ТЕРИТОРІЙ
}

\section{PARTICULARITIES OF FOOD SUPPLY IN RURAL AREAS}

\author{
Кравчук Наталія Іванівна \\ кандидат економічних наук, доцент, \\ Поліський національний університет \\ ORCID: https://orcid.org/0000-0002-0541-8057 \\ Антонець Тетяна Юріївна \\ магістрант, \\ Поліський національний університет \\ ORCID: https://orcid.org/0000-0002-2715-497X \\ Чаюн Віктор Михайлович \\ магістрант, \\ Поліський національний університет \\ ORCID: https://orcid.org/0000-0002-1256-7579
}

\author{
Kravchuk Nataliia, Antonets Tetiana, Chaiun Viktor \\ Polissia National University
}

\begin{abstract}
У статті досліджено систему поглядів на продовольче забезпечення та продовольчу безпеку. Проаналізовано сильні та слабкі сторони продовольчої безпеки України у світовому рейтингу. Встановлено основні загрози продовольчої безпеки в Україні. Розглянуто цільові орієнтири стратегії сталого розвитку щодо продовольчого забезпечення населення. Ідентифіковано індикатори продовольчої безпеки. Здійснено групування за показником індексу маси тіла задля визначення найбільш продовольчо вразливих регіонів України. Авторами досліджено головні характеристики продовольчого забезпечення сільських територій та проведено їх аналіз. Зокрема, оцінено рівень споживання основних продуктів харчування та розраховано індикатор їх достатності; проілюстровано питому вагу витрат на продукти харчування; проаналізовано рівень самозабезпечення сільського населення основними групами продовольства. Вагоме значення в статті відводиться процесу поширеності недоїдання серед населення сільських територій України та моделюванню різних сценаріїв на перспективу за методикою ФАО ООН.
\end{abstract}

Ключові слова: продовольча безпека, сталий розвиток, сільське населення, індикатори, раціон, продукти харчування, недоїдання.

В статье исследована система взглядов на продовольственное обеспечение и продовольственную безопасность. Проанализированы сильные и слабые стороны продовольственной безопасности Украины в мировом рейтинге. Установлены основные угрозы продовольственной безопасности в Украине. Рассмотрены основные целевые ориентиры стратегии устойчивого развития относительно продовольственного обеспечения населения. Идентифицированы индикаторы продовольственной безопасности. Осуществлены группировки по показателю индекса массы тела для определения наиболее продовольственно уязвимых регионов Украины. Авторами исследованы основные параметры продовольственного обеспечения сельских территорий и проведен их анализ. В частности, оценен уровень потребления основных продуктов питания и рассчитан индикатор достаточности; проиллюстрирован удельный вес расходов на продукты питания; проанализирован уровень самообеспечения сельского населения основными группами продовольствия. Большое значение в статье отводится процессам распространенности недоедания среди населения сельских территорий Украины и моделированию различных сценариев на перспективу по методике ФАО ООН.

Ключевые слова: продовольственная безопасность, устойчивое развитие, сельское население, индикаторы, рацион, продукты питания, недоедание.

The article investigates the system of views on food security and reveals the differences in its interpretation in the process of category evolution depending on the global problems and international cooperation aimed on their 
solving. The strengths and weaknesses of Ukraine's food security in the world ranking of global food security were analyzed. The main threats to food security in Ukraine are identified, such as: corruption, food standards, government spending on agricultural research in agriculture, GDP per capita, and political instability. The main targets of sustainable development strategy concerning food supply of the population are considered. Indicators of food security are distinguished, in particular: daily energy value and composition of the human ration; sufficiency of state grain reserves; economic affordability of products; differentiation of the food cost by social groups; capacity of the domestic market of certain products and food independence. The grouping by the body mass index for identification of the most food vulnerable regions of Ukraine was carried out. The authors researched the main characteristics of food supply in rural areas and performed their analysis. In particular, the deviation of the energy value of food consumed by the rural population from the average rates in Ukraine was established. The consumption level of basic nutrition products was estimated and an indicator of sufficiency was calculated; the structure of monetary household expenditures and the share of expenditure on products were illustrated; the self-sufficiency level of the rural population in basic food groups was analyzed. The article pays much attention to the process of malnutrition prevalence among the population of rural areas of Ukraine and modeling of different scenarios for the future according to the UN FAO methodology. It is established that the actual prevalence of malnutrition in Ukraine is $4.0 \%$, and the number of food insecure people is 1.8 million. Under all modeling scenarios, these processes will continue to grow. The directions of overcoming food insecurity of the rural population are proposed.

Keywords: food security, sustainable development, rural population, indicators, ration, food, malnutrition.

Постановка проблеми. Однією з стратегічних цілей сталого розвитку українського суспільства є подолання голоду, що передбачає забезпечення економічної доступності продуктів харчування для всіх верств населення, безперебійне постачання продовольства навіть до найвіддаленіших сільських територій, високу якість та безпечність харчових продуктів, збалансованість раціону на рівні науково-обґрунтованих норм. Актуальність зазначеної теми на теренах України обумовлюється як загальнонаціональними проявами системної кризи: інфрляційними процесами, низькою купівельною спроможність населення, наявністю значної частини малозабезпечених та соціально незахищених домогосподарств; так і дією об'єктивних непередбачуваних надзвичайних подій, таких як військовий конфрлікт на Сході, пандемія коронавіруса COVID-19. Поряд з означеним від продовольчої захищеності населення залежить національна безпека України, що виводить проблематику на загальнонаціональний рівень.

Аналіз останніх досліджень і публікацій. Проблема продовольчої безпеки займає чільне місце в зарубіжних та вітчизняних працях. Серед останніх досліджень варто відзначити наступні.

Праці М.В. Гладія та Ю.Я. Лузана присвячені ринковим трансорормаціям аграрного сектору та їх впливу на продовольчу безпеку України [1]. Заслуговують на увагу міркування академіка про роль державної політики у поєднанні інтересів виробників різних розмірів та масштабів діяльності, а особливе значення відводить френомену селянських господарств у фрормуванні продовольчої безпеки країни.
Результати досліджень О.В. Довгаль полягають у ідентифрікації регіональних особливостей використання виробничого потенціалу сільської місцевості з позицій забезпечення продовольчої безпеки [2]. Авторка значну увагу відводить аналізу матеріально-технічного забезпечення сільськогосподарських виробників, що значно звужує результати дослідження.

В.П. Залізнюк визначає індикатори продовольчої безпеки України [3]. Пропонується 6 індикаторів, серед яких $€$ щільність автомобільних доріг, що стосується інфрраструктурного, а не продовольчого забезпечення та опосередковано впливає на продовольчу безпеку. Відтак, на нашу думку, дане наведення може слугувати фрактором, а не індикатором.

Досить інформативним $\epsilon$ аналіз основних індикаторів продовольчої безпеки Мудрака Р.П.: енергетичної цінності спожитих продуктів, рівнів споживання продовольства, достатності державних запасів зерна, структура витрат населення тощо [4]. Пізніше науковець шукає зв'язок сільських територій та продовольчої безпеки, зокрема відзначає домінуючу роль сільськогосподарського виробництва на сільських територіях, що фрормує фрізичну доступність продовольства, а вирішальну роль у забезпеченні населення продуктами тваринного походження відводить особистим селянським господарствам [5].

Водночас, окремі аспекти цієї багатогранної проблеми залишаються маловивченими та потребують окремого наукового пошуку. Авторське бачення зводиться до необхідності системного дослідження особливостей продовольчого забезпечення сільських територій, що обумовлено суттєвими відмінностями 
від фрормування продовольчої безпеки міст, зокрема: можливість самозабезпечення сільського населення продуктами харчування, питома вага продуктів тваринного походження в раціоні та їх калорійність, структура витрат сільських домогосподарств на продукти харчування тощо.

Формулювання цілей статті. Метою дослідження $\epsilon$ розробка теоретико-методологічних положень та обґрунтування науковопрактичних рекомендацій щодо підвищення рівня продовольчого забезпечення сільських територій. Об'єктом дослідження стали соціально-економічні процеси продовольчого забезпечення сільських територій.

Методика дослідження базується як на традиційних загальнонаукових методах, таких як діалектичний підхід до процесів і явищ, логічний, системний, історичний, наукового абстрагування тощо, так і специфрічних. Зокрема, індексний метод застосовано в оцінці глобального індексу продовольчої безпеки ФАО ООН у розгляді питання доступності та якості продуктів харчування в Україні, іiї рейтингу серед 113 країн світу; означенні сильних та слабких сторін продовольчого забезпечення; для визначення індикатора достатності споживання продуктів харчування населенням сільських територій та рівня самозабезпечення країни основними видами продовольства. Метод динамічних рядів дозволяє дослідити кількісну та якісну зміну показників продовольчої безпеки. Статистичні прийоми групування застосовано для пошуку закономірностей проблем недоїдання або переїдання в регіонах України. Економіко-математичний метод використано для побудови прогнозних якісних та кількісних значень процесу поширення недоїдання в країні та моделювання його різних сценаріїв.

Виклад основного матеріалу. Пошук шляхів продовольчого забезпечення не втрачає своєї актуальності на всіх етапах розвитку суспільства, а тому є досить гнучкою концепцією в контексті різних моделей та рівнів розвитку економік країн світу. Система поглядів на продовольчу безпеку почала фрормуватися лише в середині 70-х рр. минулого століття при обговоренні міжнародних проблем глобальної продовольчої кризи. Початкова увага була зосереджена насамперед на продовольчому забезпеченні - виробництво достатнього обсягу продуктів харчування та стабільності цін на основні продовольчі товари на міжнародному та національному рівнях [6]. В процесі міжнародних переговорів відбулася про- довольча конференція (1974р.) присвячена інституційним механізмам сприяння продовольчій безпеці та ряд форумів для діалогу 3 питань політики [7]. У 1983 р. ФАО розширила свою концепцію, зосередившись на забезпеченні доступу до продуктів харчування соціально вразливих категорій населення [8]. До середини 90-х рр. міжнародна спільнота 3 питань продовольчої безпеки зосередилася на проблемах недоїдання та пов'язаного 3 ним білково-енергетичного дисбалансу, що негативно впливає на активність та здоровий спосіб життя. Нині категорія еволюціонувала та проникла в усі галузі та сорери: політика, економіка, навколишнє середовище, соціальний розвиток. Вона $€$ невід'ємною складовою безпеки людини. Найбільш узагальнена інтерпретація поняття продовольчої безпеки на всіх рівнях (індивідуальному, побутовому, національному, глобальному) полягає у фрізичному, соціальному та економічному доступі у будь-який час до безпечної та поживної їжі для забезпечення дієтичних потреб та гастрономічних уподобань щодо підтримки здорової та активної життєдіяльності [9].

У світовому рейтингу глобальної продовольчої безпеки за 2019 р. Україна займає 76 місце з 113 країн світу та має 57,1 бали зі 100 можливих [10]. Сильними сторонами визнано низьку частку населення, що перебуває за глобальною межею бідності (99,9 балів), безпека харчових продуктів (95,7 балів), зниження питомої ваги витрат на їжу $(94,5)$, повноцінність раціону $(90,4$, балів), сільськогосподарські імпортні тарифи (85,5 балів). На противагу високих оцінок сильних сторін, критично низькими $€$ проблеми забезпечення продовольчої безпеки населення, серед яких: корупція (0 балів), норми харчування (0 балів), державні витрати на НДДКР у сільському господарстві (1,1 балів), ВВП на душу населення (6,8 балів), ризики політичної нестабільності $(16,7)$.

Щоб досягти запланованих показників зростання продовольчої захищеності населення стратегією сталого розвитку України встановлено ряд цільових орієнтирів: забезпечити зростання сільськогосподарського виробництва на 2 \%; створити стійкі системи виробництва продуктів харчування, що сприяють збереженню екосистем і поступово покращують якість земель та ґрунтів; досягти зростання індексу виробництва харчових продуктів до 103 \%; підвищити частку експорту харчової продукції до 51 \%; розширити площу сільськогосподарських угідь під органічним виробництвом до 1,1 \%; знизити волатиль- 
ність цін на продукти харчування до $105 \%$ тощо [11]. Головним чином вище зазначені цілі направлені на подолання голоду та розвиток сільського господарства.

Показником, який надає нам уявлення про поширеність процесу недоїдання в Україні, $€$ індекс маси тіла (табл. 1), який розраховується як відношення ваги людини до її зросту, піднесеного до квадрату.

Як свідчать дані таблиці 1, у 2020 р. індекс маси тіла менший від 18,5 \%, що вказує на недоїдання, мають 1,2 \% населення України у віці 18 років і старше. У розрізі вікових груп даний показник значно диференціюється. Найбільший відсоток людей з пониженою масо тіла у віці 20-29 років - 3,8 \% та 18-19 років 3,5 \%. Найгірша ситуація у регіонах України, де індекс маси тіла менший за 18,5: Чернігівська, Черкаська, Дніпропетровська, Запорізька області. В цих регіонах від 1,7 до 2,6 \% населення, що недоїдають (табл. 2). Причини недоїдання мають різний характер: економічний (низький рівень доходу, понад- нормова зайнятість, низька якість продуктів харчування, фрізична недоступність продовольства), соціальний (бідність, багатодітні сім'ї, слідування модним тенденціям, швидкий темп життя), медичний (хвороби травної системи, дієтичне харчування), психологічний (розлади харчової поведінки, нервова анорексія, дратівливість, депресія).

Наслідки недоїдання досліджують та детально аналізують головним чином в галузі медицини, оскільки вони впливають на здоров'я та тривалість життя. 3 економічної точки зору недоїдання економічно активного населення, зайнятого на виробництві, знижує фрізичну та розумову активність, стресостійкість, що вливає на продуктивність праці, кількість днів виходу на роботу та лікарняних у зв'язку з хворобою та тимчасовою втратою працездатності. Такі процеси негативно відображаються в кінцевому підсумку на прибутковості підприємств.

За останніми дослідженнями ВООЗ підвищеної уваги заслуговує не лише недоїдання,

Таблиця 1

Антропометричні характеристики населення України залежно від віку і статі, 2020 р.

\begin{tabular}{|l|c|c|c|c|c|c|c|c|}
\hline \multicolumn{1}{|c|}{ Показник } & Населення & \multicolumn{6}{|c|}{ у т. ч. за віковими групами, років } \\
\cline { 5 - 11 } & у віці 18 + & $\mathbf{1 8 - 1 9}$ & $\mathbf{2 0 - 2 9}$ & $\mathbf{3 0 - 3 9}$ & $\mathbf{4 0 - 4 9}$ & $\mathbf{5 0 - 5 9}$ & $\mathbf{6 0 - 6 9}$ & $\mathbf{7 0 +}$ \\
\hline Усе населення & 100 & 100 & 100 & 100 & 100 & 100 & 100 & 100 \\
\hline $\begin{array}{l}\text { у т. ч. 3 масою тіла, \%: } \\
\text { понижена (індекс маси } \\
\text { тіла менше 18,5) }\end{array}$ & 1,2 & 3,5 & 3,8 & 2,0 & 0,8 & 0,2 & 0,1 & 0,3 \\
\hline нормальна (18,5-24,9) & 42,4 & 85,8 & 69,6 & 55,7 & 42,5 & 27,5 & 25,5 & 30,5 \\
\hline надлишкова (25,0-29,9) & 39,7 & 9,7 & 22,8 & 34,5 & 40,4 & 48,8 & 48,6 & 44,2 \\
\hline $\begin{array}{l}\text { ожиріння (індекс маси } \\
\text { тіла більше 30,0) }\end{array}$ & 16,0 & 1,0 & 3,5 & 7,7 & 15,5 & 22,1 & 24,5 & 24,4 \\
\hline $\begin{array}{l}\text { крайнє ожиріння (індекс } \\
\text { маси тіла більше 30,0) }\end{array}$ & 0,7 & - & 0,3 & 0,1 & 0,8 & 1,4 & 1,3 & 0,6 \\
\hline Середня вага людини, кг & 75 & 65 & 68 & 72 & 77 & 78 & 79 & 74 \\
\hline Середній зріст людини, м & 1,69 & 1,71 & 1,71 & 1,71 & 1,70 & 1,69 & 1,68 & 1,65 \\
\hline
\end{tabular}

Джерело: побудовано автором за даними [12]

Таблиця 2

Групування регіонів України за кількістю населення з індексом маси тіла, нижче 18,5, 2020 р.

\begin{tabular}{|c|l|c|}
\hline Група & \multicolumn{1}{|c|}{ Області } & Кількість \\
\hline До 0,6 \% & $\begin{array}{l}\text { Львівська, Закарпатська, Чернівецька, Вінницька, Київська, } \\
\text { Херсонська, Луганська }\end{array}$ & 7 \\
\hline $0,7-1,6$ & $\begin{array}{l}\text { Волинська, Рівненська, Івано-Франківська, Тернопільська, } \\
\text { Хмельницька, Житомирська, Сумська, Полтавська, Харківська, } \\
\text { Кіровоградська, миколаївська, Одеська, Донецька* }\end{array}$ & 13 \\
\hline $1,7-2,6$ & Чернігівська, Черкаська, Дніпропетровська, Запорізька & 4 \\
\hline 1,2 & Україна всього & 24 \\
\hline
\end{tabular}

* - частина, підконтрольна Україні 
а й надмірна вага, як фрактор високого рівня смертності від серцево-судинних захворювань, захворювань системи кровообігу, ускладнень від коронавіруса COVID-19. Надмірна вага одна з найскладніших медико-соціальних проблем сучасності. До 2025 р. число хворих на ожиріння в світі становитиме 300 млн осіб [13]. В Україні у 2020 р. надлишкову вагу мали 39,7 \%, ожиріння - $16 \%$, що в сукупності складає більше половини населення. Високу частку з надмірною вагою у розрізі вікових категорій має населення віком 50-69 років. Серед регіонів найбільше людей 3 ожирінням проживає в Київській, Чернігівській, Черкаській, Полтавській та Херсонській областях (табл. 3).

Постановою кабінету Міністрів України [14] ідентифріковано основні індикатори про- довольчої безпеки: добова енергетична цінність раціону людини; забезпечення раціону людини основними видами продуктів; достатність запасів зерна у державних ресурсах; економічна доступність продуктів; диференціація вартості харчування за соціальними групами; ємність внутрішнього ринку окремих продуктів; продовольча незалежність за окремим продуктом. Інтерес викликають дослідження вказаних індикаторів на сільських територіях, оскільки їх продовольча захищеність значно відрізняється від міських населених пунктів та має свої особливості.

Таблиця 4 ілюструє калорійність добового раціону сільського мешканця в Україні. У 2019 р. вона становила 3184 ккал, що перевищує граничний рівень на 493 ккал. Водно-

\section{Групування регіонів України за кількістю населення}

Таблиця 3 з індексом маси тіла, вище 30,0, 2020 р.

\begin{tabular}{|c|l|c|}
\hline Група & \multicolumn{1}{|c|}{ Області } & Кількість \\
\hline $12,5-16,4 \%$ & $\begin{array}{l}\text { Волинська, Рівненська, Львівська, Івано-Франківська, Вінницька, } \\
\text { Одеська, Миколаївська, Дніпропетровська, Сумська, Харківська, } \\
\text { Луганська, Донецька }\end{array}$ & 12 \\
\hline $16,5-18,9 \%$ & $\begin{array}{l}\text { Закарпатська, Чернівецька, Тернопільська, Хмельницька, } \\
\text { Житомирська, м. Київ, Кіровоградська, Запорізька }\end{array}$ & 7 \\
\hline $19,0-24,6 \%$ & Київська, Чернігівська, Черкаська, Полтавська, Херсонська & 5 \\
\hline $16,7 \%$ & Україна всього & 24 \\
\hline
\end{tabular}

Джерело: побудовано авторами за даними [12]

Таблиця 4

Енергетична цінність та вміст поживних речовин у спожитих сільським населенням продуктах харчування, у середньому за добу у розрахунку на 1 особу, 2019 р.

\begin{tabular}{|l|c|c|c|}
\hline \multicolumn{1}{|c|}{ Показник } & $\begin{array}{c}\text { Всі } \\
\text { домогосподарства }\end{array}$ & $\begin{array}{c}\text { Господарства } \\
\text { сільських } \\
\text { територій }\end{array}$ & $\begin{array}{c}\text { Відхилення } \\
\text { від середнього } \\
\text { значення } \\
\text { по Україні, +/- }\end{array}$ \\
\hline Енергетична цінність, ккал & 2951 & 3184 & 233 \\
\hline $\begin{array}{l}\text { відхилення від граничного } \\
\text { рівня (2691 ккал), +/- }\end{array}$ & 260 & 493 & 233 \\
\hline $\begin{array}{l}\text { Продукти рослинного } \\
\text { походження, ккал }\end{array}$ & 1891 & 2184 & 293 \\
\hline у \% до загальної калорійності & 70,3 & 68,7 & $-1,6$ \\
\hline $\begin{array}{l}\text { відхилення від нормативного } \\
\text { рівня (45\%), +/- }\end{array}$ & 25,3 & 23,7 & $-1,6$ \\
\hline $\begin{array}{l}\text { Продукти тваринного } \\
\text { походження, ккал }\end{array}$ & 800 & 1000 & 200 \\
\hline у до загальної калорійності & 29,7 & 31,3 & 1,6 \\
\hline $\begin{array}{l}\text { відхилення від нормативного } \\
\text { рівня (55 \%), +/- }\end{array}$ & $-25,3$ & $-23,7$ & 1,6 \\
\hline Білки, г & 85 & 90 & 5 \\
\hline Жри, г & 134 & 137 & 3 \\
\hline Вуглеводи, г & 357 & 408 & 51 \\
\hline
\end{tabular}


час, за даними міжнародної організації ФАО середньодобова енергетична цінність раціону одного європейця становить 3400-3500 ккал і продовжує зростати, а питома вага продуктів тваринного походження - 29-30 \% [15].

Варто відзначити, що згідно рекомендацій ВОО3 оптимальна норма калорійності раціону коригується залежно від вікової групи (діти, підлітки, дорослі,) статі (жінки, чоловіки), фрізичної активності (працівники особливо важкої срізичної праці, спортсмени). У сільському господарстві населення активно зайняте важкою фрізичною працею та працює ненормований робочий день. Обслуговування особистого селянського господарства, яке нині поширене на сільських територіях України, вимагає значних затрат енергії, тому перевищення показника від середньодержавного рівня $€$ обґрунтованим $з$ економічної та медичної точок зору.

Важливого значення має частка спожитих продуктів тваринного походження у добовому раціоні. Нормативним рівнем за даними ФАО вважається показник на рівні $55 \%$. Ми ж маємо недоспоживання цієї продукції на 23,7 \% та перевищення норми споживання продукції рослинного походження на цю саму величину відповідно.

Важливими показниками продовольчої захищеності населення $є$ відповідність спожи- вання основних продуктів харчування однією особою встановленим нормативам МО3 та індикатор достатності. Розрахунки свідчать, що на сільських територіях України перевищує встановлені норми споживання найбільш економічно доступних групи харчових продуктів таких як: хліб (на 12 \%), олія (у 2 рази), овочі, у тому числі картопля (на 22 \%) (табл. 5).

Наразі, суттєве недоспоживання стосується найбільш дорогих груп харчових продуктів: м'яса, молока, фрруктів та ягід майже у два рази кожна, риби - на $18 \%$, яєць - на $21 \%$ менше встановленої норми. Разом 3 тим, варто зауважити, що сільське населення завдяки особистому господарству значною мірою забезпечує себе власноруч вирощеними продуктами харчування: на 32 \% фруктами, ягодами; на $35 \%$ жирами; на $37 \%$ м'ясом; на 50 \% молоком; на $90 \%$ яйцями; на $91 \%$ овочами. Такі тенденції визначають головним чином особливості продовольчого забезпечення сільських територій на відміну від міських населених пунктів. Селяни в умовах низької платоспроможності, відсутності альтернатив працевлаштування змушені самозабезпечувати свої сім'ї традиційним для них способом. За статистичними даними у структурі доходів сільських домогосподарств вартість спожитої продукції 3 особистого підсобного господарства становить 9,5 \%,

Споживання продуктів харчування на сільських територіях України,

Таблиця 5 у середньому за місяць у розрахунку на одну особу

\begin{tabular}{|c|c|c|c|c|c|c|c|}
\hline \multirow[b]{2}{*}{ Вид продукту } & \multirow[b]{2}{*}{$\begin{array}{l}\text { Норматив } \\
\text { (МО3) }\end{array}$} & \multicolumn{3}{|c|}{2018 p. } & \multicolumn{3}{|c|}{2019 p. } \\
\hline & & 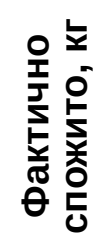 & 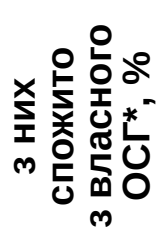 & 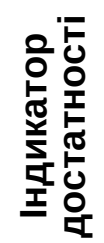 & 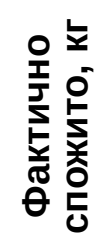 & 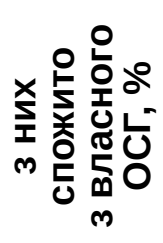 & 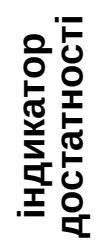 \\
\hline Хліб і хлібопродукти & 8,4 & 9,6 & 2,2 & 1,14 & 9,4 & 1,3 & 1,12 \\
\hline $\begin{array}{l}\text { М'ясо та } \\
\text { м'ясопродукти }\end{array}$ & 6,7 & 3,7 & 40,3 & 0,55 & 4,0 & 37,1 & 0,60 \\
\hline Риба та рибопродукти & 1,7 & 1,3 & 2,5 & 0,76 & 1,4 & 2,5 & 0,82 \\
\hline $\begin{array}{l}\text { Молоко і } \\
\text { молокопродукти }\end{array}$ & 31,7 & 14,0 & 48,6 & 0,44 & 13,7 & 49,7 & 0,43 \\
\hline Яйця, шт. & 24,2 & 18 & 91,9 & 0,74 & 19 & 89,8 & 0,79 \\
\hline Олія та жири & 1,1 & 2,4 & 37,6 & 2,18 & 2,3 & 35,3 & 2,09 \\
\hline Фрукти, ягоди, горіхи & 7,5 & 3,6 & 35,3 & 0,48 & 3,7 & 32,1 & 0,49 \\
\hline $\begin{array}{l}\text { Овочі (у т. ч. картопля) } \\
\text { та баштанні }\end{array}$ & 13,4 & 16,5 & 95,1 & 1,23 & 16,3 & 90,9 & 1,22 \\
\hline Цукор, мед & 3,2 & 2,9 & 7,3 & 0,91 & 2,9 & 6,8 & 0,91 \\
\hline
\end{tabular}

* ОСГ - особисте селянське господарство. 
доходи від продажу сільськогосподарської продукції 7,4 \%, доходи від підприємницької діяльності та самозайнятості - 4,8 \%, що в сукупності становить 21,7\%.

У структурі грошових витрат домогосподарств України найбільша питома вага доводиться на продовольчі товари - 42,05 \% (для порівняння на непродовольчі товари витрачається $26,5 \%$, оплату послуг - 15,1\%). У розрізі типів населених пунктів у міських поселеннях цей показник вищий - 44,2 \%, тоді як у сільських домогосподарствах - 39,9 \% (табл. 6).

У 2019 р. одне домогосподарство витрачало на продукти харчування 3832,75 грн в місяць (у 2018 р. - 3366,96 грн). У сільській місцевості такі грошові витрати значно менші від середніх по Україні - 2987,04. Коефріцієнт децильності 1,38 свідчить про значну диференціацію витрат на продукти харчування $10 \%$ найбагатшого сільського населення відносно $10 \%$ найбіднішого.

Граничною вважається частка витрат на продовольство - 60 \%. В середньому в Україні у всіх типах домогосподарств вона становить $51 \%$, що наближено до граничного рівня. На сільських територіях на харчові продукти селяни витрачають значно менше - 40 \%. Водночас, порівняно з країнами $€ С$, де вона в середньому становить 13,1 \% (від 7,8 \% в Великобританії до 36,7 \% в Білорусії) українці майже в 4 рази перевищують середньоєвропейський показник [18].

Про рівень життя сільського населення свідчить диференціація вартості харчування за соціальними групами сільських територій. Найбільш незахищеним $є$ населення, що має сукупні грошові доходи, нижчі законо- давчо встановленого прожиткового мінімуму (1902,08 грн), нижче орактичного прожиткового мінімуму (3660,94 грн) та нижче середнього рівня грошових доходів (4409,75 грн). Відстежувати даний показник пропонується, порівнюючи вартість харчування домогосподарств цих груп (табл. 7).

Найбільше грошових витрат доводиться на споживання хліба і хлібопродуктів - 23,0 \% та м'яса і м'ясопродуктів - 20,5\%. Це дві групи продовольства, що мають протилежні тенденції споживання. Економічне обґрунтування отриманих результатів наступне: за попередніми дослідженнями хліб та хлібопродукти споживаються понаднормово на сільських територіях, оскільки це економічно доступний продукт. Висока питома вага у структурі витрат на м'ясо пояснюється не обсягами споживання, на відміну від попередньої продовольчої групи, а високою ціною на ринку.

Важливим показником продовольчої захищеності населення вважається рівень самозабезпеченості країни продовольством за основними групами. Експертами інсрормаційноаналітичного порталу АПК України [16] розраховано динаміку даного показника та визначено імпортозалежність окремих груп (табл. 8).

Україна має високий рівень самозабезпеченості олією - 1368 \%, що визначає експортну спрямованість та лідерство на світовому ринку соняшникової олії. У динаміці за чотири роки спостерігається зростання забезпеченості країни зерном на 102 в.п. - $3239 \%$ до $341 \%$, що теж пояснює високий рівень споживання населенням хліба і хлібопродуктів. Інші продовольчі групи також виробляються в

Структура витрат домогосподарств сільських територій України у розрахунку на 1 домогосподарство в місяць, 2019 р.

\begin{tabular}{|l|c|c|}
\hline \multicolumn{1}{|c|}{ Показник } & Грн & \% \\
\hline Грошові витрати, всього & 7492,64 & 100 \\
\hline Продукти харчування, грн & 2987,04 & 39,87 \\
\hline Одяг та взуття & 504,77 & 6,74 \\
\hline Житло, вода, електроенергія, газ & 1034,41 & 13,81 \\
\hline Охорона здоров'я & 352,20 & 4,70 \\
\hline Транспорт і зв'язок & 567,75 & 7,58 \\
\hline Відпочинок і культура & 63,27 & 0,84 \\
\hline Освіта & 49,56 & 0,66 \\
\hline $\begin{array}{l}\text { Витрати на продукти харчування } \\
\text { 1-ї децильної групи, грн }\end{array}$ & 3832,75 & 52,6 \\
\hline $\begin{array}{l}\text { Витрати на продукти харчування } \\
\text { 10-ї децильної групи, грн }\end{array}$ & 5278,93 & 33,6 \\
\hline Коесріцієнт децильності & 1,38 & $\mathrm{X}$ \\
\hline
\end{tabular}

Таблиця 6 
Грошові витрати сільських домогосподарств на харчування

Таблиця 7 залежно від розміру середньодушових еквівалентних грошових доходів, 2019 р. (в розрахунку на одне домогосподарство)

\begin{tabular}{|l|c|c|c|c|c|}
\hline \multicolumn{1}{|c|}{ Вид продукту } & $\begin{array}{c}\text { Всього, } \\
\text { грн }\end{array}$ & \% & $\begin{array}{c}\text { Нижче } \\
\text { законодавчо } \\
\text { встановленого } \\
\text { прожитового } \\
\text { мінімуму } \\
\text { (1902,08 грн) }\end{array}$ & $\begin{array}{c}\text { Нижче } \\
\text { орактичного } \\
\text { пожиткового } \\
\text { мінімуму } \\
\text { (3660,94 грн) }\end{array}$ & $\begin{array}{c}\text { Нижче } \\
\text { середнього } \\
\text { рівня } \\
\text { грошових } \\
\text { доходів } \\
\text { (4409,54 грн) }\end{array}$ \\
\hline Продукти харчування & 2987,04 & 100 & 2015,06 & 2453,16 & 2808,75 \\
\hline $\begin{array}{l}\text { у т.ч. } \\
\text { хлібі хлібопродукти }\end{array}$ & 686,99 & 23,0 & 559,26 & 625,81 & 670,92 \\
\hline м'ясо та м'ясопродукти & 611,51 & 20,5 & 406,18 & 462,60 & 553,85 \\
\hline риба та рибопродукти & 224,86 & 7,5 & 141,78 & 177,32 & 207,18 \\
\hline молоко, сир, яйця & 297,3 & 10,0 & 172,53 & 244,85 & 229,12 \\
\hline олія та жири & 309,01 & 10,3 & 218,46 & 280,37 & 297,58 \\
\hline фррукти & 133,18 & 4,5 & 102,58 & 120,73 & 125,05 \\
\hline овочі & 185,85 & 6,2 & 129,58 & 143,23 & 178,59 \\
\hline $\begin{array}{l}\text { цукор та цукровмісні } \\
\text { продукти }\end{array}$ & 262,14 & 8,8 & 142,31 & 208,57 & 244,18 \\
\hline
\end{tabular}

Джерело: побудовано авторами за даними [17]

Таблиця 8

Рівень самозабезпечення основними групами продовольства в Україні, \%

\begin{tabular}{|l|c|c|c|c|c|c|c|}
\hline \multicolumn{1}{|c|}{ Вид продукції } & $\mathbf{2 0 1 5}$ p. & $\mathbf{2 0 1 6}$ р. & $\mathbf{2 0 1 7}$ р. & $\mathbf{2 0 1 8}$ р. & $\mathbf{2 0 1 9}$ р. & +l- в.п. & $\begin{array}{c}\text { Імпорто- } \\
\text { залежність, \% }\end{array}$ \\
\hline Зернові & 239 & 291 & 293 & 319 & 341 & 102 & 3,1 \\
\hline М'ясо і м'ясопродукти & 107 & 106 & 106 & 106 & 111 & 4 & 12,7 \\
\hline Молоко і молокопродукти & 105 & 104 & 108 & 107 & 103 & -2 & 2,2 \\
\hline Яйця & 116 & 107 & 115 & 124 & 126 & 10 & 0,6 \\
\hline Картопля & 96 & 102 & 102 & 101 & 93 & -3 & 0,5 \\
\hline Овочі & 212 & 224 & 444 & 434 & 284 & 36 & 2,7 \\
\hline Плоди, ягоди & 92 & 85 & 83 & 91 & 78 & -14 & 35,9 \\
\hline Цукор & 89 & 135 & 150 & 132 & 115 & 26 & 0,2 \\
\hline Олія & 873 & 1088 & 1266 & 1246 & 1368 & 495 & 0,2 \\
\hline Риба та рибопродукти & 38 & 31 & 29 & 26 & 24 & 6 & 79,3 \\
\hline
\end{tabular}

Джерело: побудовано авторами за даними [16]

достатній та вище достатньої кількості: яйця $126 \%$, цукор - $115 \%$, м'ясо - $111 \%$, молоко $103 \%$. Недостатньо вирощується у динаміці плодів та ягід - 78 \% від потреби. У 2015 р. та 2019 р. спостерігалося недовиробництво картоплі, що пояснюється несприятливими погодними умовами для вирощування цієї культури. Найгірше забезпечене населення України рибою і рибопродуктами, що визначає високу імпортозалежність на рівні 79,3 \%. Даний показник розрахований аналітиками порталу АПК України як відношення обсягів імпорту до місткості внутрішнього ринку в натуральних одиницях та встановлений його граничний критерій на рівні $30 \%$.
Провівши глибокий аналіз сучасних тенденцій та проблем продовольчого забезпечення в Україні від загальнодержавного рівня до окремих домогосподарств сільських територій, доцільним вбачається розробка сценаріїв продовольчого забезпечення на віддалену перспективу, що є предметом дослідження провідних міжнародних організацій 3 вирішення шляхів подолання голоду, як глобальної проблеми планетарного масштабу. Для прогнозування поширеності недоїдання та кількості голодного населення України у 2018-2030 рр. застосуємо методику, запропоновану міжнародною організацією ФАО ООН. Їх звіт про стан продовольчої безпеки і спожи- 
Таблиця 9

Вихідні розрахунки для визначення показників поширеності недоїдання (PoU, NoU) серед населення сільських територій України

\begin{tabular}{|c|c|c|c|c|c|c|c|}
\hline Показник & $\begin{array}{c}\text { Од. } \\
\text { виміру }\end{array}$ & 2015 p. & 2016 p. & 2017 p. & 2018 p. & 2019 p. & $\begin{array}{r}\text { Середнє } \\
\text { значення }\end{array}$ \\
\hline $\begin{array}{l}\text { Енергетична цінність } \\
\text { добового раціону селянина }\end{array}$ & ккал & 2799 & 2742 & 2707 & 2706 & 2691 & 2729 \\
\hline $\begin{array}{l}\text { Середньорічний темп } \\
\text { зростання енергетичної } \\
\text { цінності раціону (DES) }\end{array}$ & $\%$ & $x$ & $-2,03$ & $-1,28$ & $-0,04$ & $-0,55$ & $-0,98$ \\
\hline $\begin{array}{l}\text { Середньодушовий } \\
\text { еквівалентний дохід селянина }\end{array}$ & грн & 4948,7 & 4924 & 4900,1 & 4873,6 & 4844,2 & 4898,12 \\
\hline Стандартне відхилення доходів & грн & & & & & & 41,05 \\
\hline Середнє арифметичне доходів & грн & & & & & & 4898,12 \\
\hline Коефріцієнт варіації доходів (CV) & $\%$ & & & & & & 0,84 \\
\hline
\end{tabular}

вання продуктів харчування в світі у 2020 р. доповнено цифрровим інструментом прогнозування, що дозволяє самостійно контролювати та прогнозувати рівень поширеності голоду (показники PoU, NoU) [19].

Вихідні умови для побудови прогнозу (табл. 9):

1. Річний темп зростання енергоспоживання (DES), ккал, \% -0,98;

2. Коефіцієнт варіації доходів (CV), як відношення стандартного відхилення до середнього арифрметичного помножене $100 \%-0,84$.

Прогноз будувався як на основі вже розрахованих експертами ФОА показників продовольчого забезпечення України за попередні періоди до 2015 р., що внесені у базу даних ФОА, в тому числі коефріцієнтів варіації доходів CV 2,95 і CV -3,8, так і розрахованими авторами даного дослідження DES -0,98 та CV 0,84, передбачених методикою. В резуль-
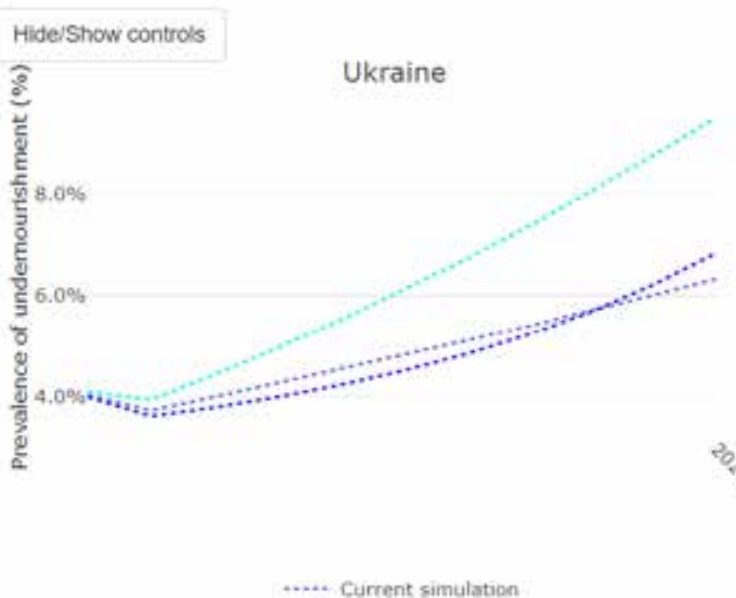

..... Simulation 1: DeS $-2.03 \%$ \& CV $-3.89 \%$

Simulation 2: DES $-0.98 \%$ \& CV $2.59 \%$

Рис. 1. Прогноз поширеності недоїдання в Україні, \%

Джерело: власні дослідження таті отримуємо прогнозні величин поширеності недоїдання в Україні (PoU, \%) (рис. 1) та прогноз кількості людей, що недоїдають (NoU, млн осіб) (рис. 2).

Сценарне прогнозування різних варіантів розвитку подій зведемо у таблицю 10.

Сценарій 1 можливий за умов продовження тенденцій, що зберігалися до 2016 р., коли спостерігався процес зниження доходів та енергетичної цінності раціону. Сценарій 2 за умов врахування середніх значень темпів зростання добової енергетичної цінності раціону 32016 р. по 2019 р. та зростання коефіцієнту варіації доходів 2,59 \%. Поточне моделювання побудоване виключно на середніх значеннях останніх тенденцій за період 2016-2019 pp.

3 таблиці 10 видно, що фрактична поширеність недоїдання в Україні знаходиться на

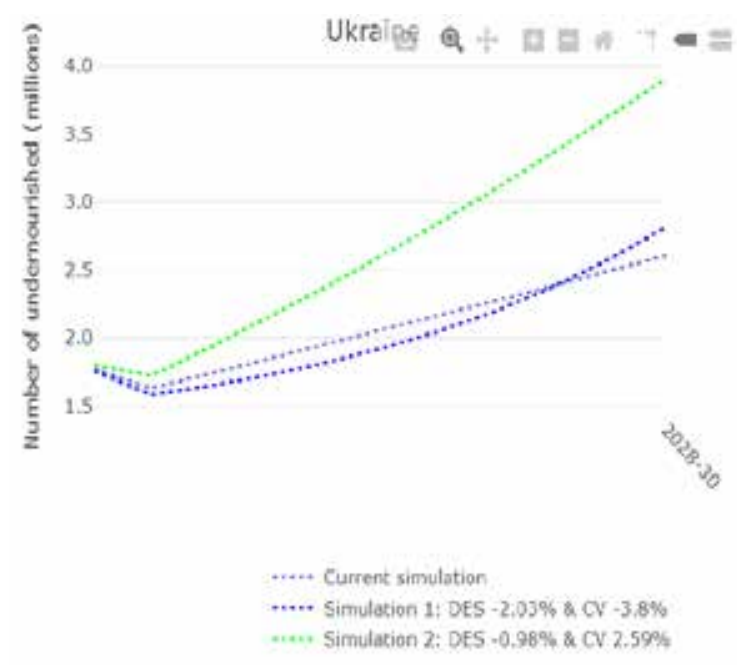

Рис. 2. Прогноз кількості людей, що недоїдають, млн осіб Джерело: власні дослідження 
Таблиця 10

Прогнозування процесу поширеності недоїдання серед населення сільських територій України до 2030 р.

\begin{tabular}{|c|c|c|c|c|c|}
\hline & \multirow[b]{2}{*}{ Показник } & \multirow{2}{*}{$\begin{array}{c}\text { Фактичний } \\
\text { рівень } \\
\text { (2018-2020 рр.) }\end{array}$} & Сценарій 1 & Сценарій 2 & $\begin{array}{c}\text { Поточне } \\
\text { моделювання }\end{array}$ \\
\hline & & & $\begin{array}{c}\text { Умова: } \\
\text { DES-2.03\% } \\
\text { CV-3,8\% }\end{array}$ & $\begin{array}{c}\text { Умова: } \\
\text { DES-0.98\% } \\
\text { CV-2.59\% }\end{array}$ & $\begin{array}{c}\text { Умова: } \\
\text { DES-0.98\% } \\
\text { CV-3.8\% }\end{array}$ \\
\hline 1 & $\begin{array}{l}\text { Поширеність недоїдання } \\
\text { в Україні, \% }\end{array}$ & 4,0 & 6,8 & 9,5 & 6,3 \\
\hline 2 & $\begin{array}{l}\text { Кількості людей, } \\
\text { що недоїдають, млн осіб }\end{array}$ & 1,8 & 2,8 & 3,9 & 2,6 \\
\hline
\end{tabular}

Джерело: власні дослідження

рівні 4,0 \%, а кількість продовольчо незахищених людей - 1,8 млн осіб. За усіма сценаріями моделювання ці процеси продовжуватимуть набирати обертів. При чому, за сценарієм 2 найбільш песимістичний прогноз - 3,9млн населення. Не дивлячись на фрактичне зростання доходів сільського населення, інорляційні процеси не дозволяють підвищити добробут та досягти продовольчої безпеки.

За умов збереження тенденцій останнього десятиліття у світі в цілому прогнози свідчать, що досягти нульового голоду у 2030 р. не вдасться, не зважаючи на певний прогрес в економічно розвинутих країнах світу. Головною причиною $€$ погіршення продовольчої безпеки та харчового статусу найбільш вразливих категорій населення внаслідок пандемії КОВІД-2019.

Висновки та перспективи подальших досліджень. Підсумовуючи проведені дослідження можемо зробити наступні узагальнення:

1. Продовольче забезпечення $€$ складовою поняття «продовольча безпека» та означає виробництво достатнього обсягу продуктів харчування та стабільність цін на основні продовольчі товари на міжнародному та національному рівнях. Найбільш узагальнена інтерпретація поняття продовольчої безпеки полягає у фрізичному, соціальному та економічному доступі у будь-який час до безпечної та поживної їжі для забезпечення дієтичних потреб та гастрономічних уподобань людини, ії здорової та активної життєдіяльності.

2. Встановлено, що у світовому рейтингу глобальної продовольчої безпеки за 2019 р. Україна займає 76 місце з 113 країн світу. Критичними є проблеми, що загрожують продовольчій безпеці населення, серед яких: висока корумпованість, низькі державні витрати на НДДКР у сільському господарстві, низький ВВП на душу населення, високі ризики полі- тичної нестабільності, невідповідність раціону нормам харчування.

3. Основними критеріями (індикаторами) продовольчого забезпечення є: добова енергетична цінність раціону людини; забезпечення раціону людини основними видами продуктів; достатність запасів зерна у державних ресурсах; економічна доступність продуктів; диференціація вартості харчування за соціальними групами; ємність внутрішнього ринку окремих продуктів; продовольча незалежність за окремим продуктом.

4. Дослідження показали, що на сільських територіях України енергетична цінність та поживність спожитих за добу продуктів харчування одним мешканцем $€$ вищою від середнього державного рівня на 233 ккал, але нижчою від середньоєвропейського на 316 ккал. Питома вага продуктів тваринного походження майже вдвічі нижча (31,3 \%) від рекомендованих норм (55,0 \%).

5. Аналіз споживання продуктів харчування за основними продовольчими групами довів, що внаслідок низької купівельної спроможності сільського населення спостерігається суттєве недоспоживання м'яса, молока, фрруктів та ягід, не дивлячись на те, що сільське населення самозабезпечує себе цими продуктами на 37 \%, 50 \%, 32 \% відповідно.

6. Дослідження ілюструють високу питому вагу витрат сільських домогосподарств на продукти харчування у структурі загальних середньомісячних витрат - 40 \%. Найбільше коштують сімейному бюджету через високу ціну - м'ясо (20,5 \%), внаслідок великих обсягів споживання - хліб $(23,0 \%)$.

7. За результатами проведеного аналізу Україна має високий рівень самозабезпеченості наступними продуктами харчування: олією - 1368 \%, зерном - $341 \%$, овочами $284 \%$. Достатній рівень виробництва яєць $126 \%$, цукру - $115 \%$, м'яса - $111 \%$. Критично 
низький рівень забезпечення рибою та рибопродуктами - $24 \%$, що фрормує імпортозалежність країни.

8. Моделювання та прогнозування продовольчого забезпечення сільського населення свідчать, що негативні процеси поширеності недоїдання будуть зростати з 4,0 \% до 9,5\% за найгіршим сценарієм, та до 6,8 \% за опти- містичним. Прогнозна кількість людей, що недоїдають, до 2030 р. становитиме від 2,6 до 3,9 млн за різними сценаріями.

Відтак, перспективою подальших досліджень стане науковий пошук шляхів запобігання поширення процесів продовольчої незахищеності населення України, в тому числі сільських територій.

\section{СПИСОК ВИКОРИСТАНИХ ДЖЕРЕЛ:}

1. Гладій М.В., Лузан Ю.Я. Аграрні транссормації та селянські господарства в системі продовольчої безпеки України. Економіка АПК. 2020. № 5. С. 6-21. doi: 10.32317/2221-1055.202005006

2. Довгаль О. Виробничий потенціал сільських територій: стан та рівень використання в умовах забезпечення продовольчої безпеки регіону. Economic and Food Security of Ukraine. 2019. № 6(3-4). С. 65-73. doi: $10.15673 /$ efs.v6i3-4.1288

3. Залізнюк В.П. Оцінка індикаторів продовольчої безпеки України. Інвестиції: практика та досвід. 2019. № 2. C. 128-133. doi: 10.32702/2306-6814.2019.2.128

4. Мудрак Р.П. Продовольча безпека в умовах кризи. Збірник наукових праць Уманського НУС. 2017. Вип. 90. Ч. 2. С. $115-127$.

5. Мудрак Р.П., Нижник І.О. Розвиток сільських територій та продовольча безпека держави. Збірник наукових праць Уманського НУС. 2019. Вип. 92. Ч. 2. Р. 131-140. doi: 10.31395/2415-8240-2019-94-2-131-140

6. United Nations (1975) Report of the World Food Conference, Rome 5-16 November 1974. New York. Available at: https://digitallibrary.un.org/record/701143

7. FAO (2003) Trade Reforms and Food Security. Chapter 2. Food security: concepts and measurement. Available at: http://www.fao.org/3/y4671e/y4671e06.htm

8. Huddleston, B. (1990) FAO's Overall Approach and Methodology for Formulating National Food Security Programmes in Developing Countries. IDS Bulletin. Vol. 21. No. 3. P. 72-80. Institute of Development Studies. Available at: https://core.ac.uk/download/pdf/43540472.pdf

9. FAO (2002) The State of Food Insecurity in the World 2001. Rome. Available at: http://www.fao.org/3/y1500e/ y1500e00.htm

10. FAO (2020) Global Food Security Index. Available at: https://foodsecurityindex.eiu.com/Country/ Details\#Ukraine

11. Цілі сталого розвитку. Україна 2020 : Моніторинговий звіт. Державна служба статистики України. URL: http://uww.ukrstat.gov.ua/csr_prezent/ukr/st_rozv/publ/SDGs\%20Ukraine\%202020\%20Monitoring_12.2020ukr.pdf

12. Соціально-демографічні характеристики домогосподарств України у 2020 році : Статистичний збірник. Державна служба статистики України. Київ, 2020. 88 c. URL: http://www.ukrstat.gov.ua/druk/publicat/kat_u/2020/ zb/07/zb_cdhd_20.pdf

13. Ожиріння - проблема сучасності. Департамент охорони здоров'я Чернівецької обласної державної адміністрації. URL: https://www.medcv.gov.ua/archives/25773

14.Деякі питання продовольчої безпеки : Постанова КМУ № 1379 від 05.12.2007 р. Офріційний сайт. URL: https://zakon.rada.gov.ua/laws/show/1379-2007-\%D0\%BF\#Text

15. FAO (2012) European and Central Asian Agriculture Towards 2030 and 2050. Regional Office for Europe and Central Asia Policy Studies on Rural Transition No. 2012-1. Available at: http://www.fao.org/3/a-aq341e.pdf

16. Інформаційно-аналітичні матеріали щодо стану продовольчої безпеки в Україні. Офріційний сайт. Інформаційно-аналітичний портал АПК України. URL: https:/lagro.me.gov.ua/storage/app/ sites/1/stanAPK_pdf_zvity/\%D0\%90\%D0\%9F\%D0\%9A\%202020/\%20\%D0\%B7\%D0\%B0\%202019\%20 \%D1\%80\%D1\%96\%D0\%BA_1.pdf

17. Витрати і ресурси домогосподарств України у 2019 році : Статистичний збірник. Частина 1. Державна служба статистики України. Київ, 2020. URL: http://www.ukrstat.gov.ua/druk/publicat/kat_u/2020/zb/06/zb_ vrd_19_ue.pdf.

18. Експрес-огляд основних індикаторів продовольчої безпеки в Україні у 2019 році. Економічний дискусійний клуб. URL: http://edclub.com.ua/analityka/ekspres-oglyad-osnovnyh-indykatoriv-prodovolchoyi-bezpeky-vukrayini-u-2019-roci

19. FAO (2020) The State of Food security and Nutrition in the World 2020. Prevalence of Undernourishment (PoU) projection tool. Available at: http://www.fao.org/publications/sofi/en/ 


\section{REFERENCES:}

1. Hladii, M.V., \& Luzan, Yu.Ya. (2020) Ahrarni transformatsii ta selianski hospodarstva v systemi prodovolchoi bezpeky Ukrainy [Agrarian transformations and farms in the food security system of Ukraine]. Ekonomika APK [Economics of agro-industrial complex], no. 5, pp. 6-21. doi: 10.32317/2221-1055.202005006 (in Ukrainian)

2. Dovhal, O. (2019) Vyrobnychyi potentsial silskykh terytorii: stan ta riven vykorystannia v umovakh zabezpechennia prodovolchoi bezpeky rehionu [Production potential of rural areas: the state and level of use in terms of food security in the region]. Economic and Food Security of Ukraine, no. 6(3-4), pp. 65-73. doi: 10.15673/efs.v6i3-4.1288 (in Ukrainian)

3. Zalizniuk, V. (2019) Otsinka indykatoriv prodovolchoi bezpeky Ukrainy [Estimation of the food security indicators of Ukraine]. Investytsiyi: praktyka ta dosvid [Investments: practice and experience], vol. 2. pp. 128-133. doi: 10.32702/2306-6814.2019.2.128 (in Ukrainian)

4. Mudrak, R.P. (2017) Prodovolcha bezpeka v umovakh kryzy [Food security in a crisis]. Zbirnyk naukovykh prats Umanskoho NUS [Collection of scientific works of Uman NUS], no. 90(2), pp. 115-127. (in Ukrainian)

5. Mudrak, R.P., \& Nyzhnyk I.O. (2019) Rozvytok silskykh terytorii ta prodovolcha bezpeka derzhavy [Rural development and food security of the state]. Zbirnyk naukovykh prats Umanskoho NUS [Collection of scientific works of Uman NUS], no. 92(2), pp. 131-140. doi: 10.31395/2415-8240-2019-94-2-131-140 (in Ukrainian)

6. United Nations (1975) Report of the World Food Conference, Rome 5-16 November 1974. New York. Available at: https://digitallibrary.un.org/record/701143

7. FAO (2003) Trade Reforms and Food Security. Chapter 2. Food security: concepts and measurement. Available at: http://www.fao.org/3/y4671e/y4671e06.htm

8. Huddleston, B. (1990) FAO's Overall Approach and Methodology for Formulating National Food Security Programmes in Developing Countries. IDS Bulletin, vol. 21, no. 3, pp. 72-80. Institute of Development Studies. Available at: https://core.ac.uk/download/pdf/43540472.pdf

9. FAO (2002) The State of Food Insecurity in the World 2001. Rome. Available at: http://www.fao.org/3/y1500e/ y1500e00.htm

10.FAO (2020) Global Food Security Index. Available at: https://foodsecurityindex.eiu.com/Country/ Details\#Ukraine

11. Tsili staloho rozvytku. Ukraina 2020: Monitorynhovyi zvit [Sustainable development goals. Ukraine 2020: Monitoring report]. Derzhavna sluzhba statystyky Ukrainy [State Statistics Service of Ukraine]. Available at: http://www.ukrstat.gov.ual csr_prezent/ukr/st_rozv/publ/SDGs\%20Ukraine\%202020\%20Monitoring_12.2020ukr.pdf (in Ukrainian)

12. Sotsialno-demohrafichni kharakterystyky domohospodarstv Ukrainy u 2020 rotsi: Statystychnyi zbirnyk [Socio-demographic characteristics of Ukrainian households in 2020: Statistical collection]. Derzhavna sluzhba statystyky Ukrainy [State Statistics Service of Ukraine]. Available at: http://www.ukrstat.gov.ua/druk/publicat/kat_u/2020/ zb/07/zb_cdhd_20.pdf (in Ukrainian)

13. Ozhyrinnia - problema suchasnosti [Obesity is a problem of our time]. Departament okhorony zdorovia Chernivetskoi oblasnoi derzhavnoi administratsii [Health Department of Chernivtsi Regional State Administration]. Available at: https://www.medcv.gov.ua/archives/25773 (in Ukrainian)

14. Deiaki pytannia prodovolchoi bezpeky [Some food security issues]: Postanova KMU № 1379 vid 05.12.2007 r. Ofitsiinyi sait [Resolution of the Cabinet of Ministers of Ukraine №1379 of December 5, 2007. Official website]. Available at: https://zakon.rada.gov.ua/laws/show/1379-2007-\%D0\%BF\#Text (in Ukrainian)

15. FAO (2012) European and Central Asian Agriculture Towards 2030 and 2050. Regional Office for Europe and Central Asia Policy Studies on Rural Transition No. 2012-1. Available at: http://www.fao.org/3/a-aq341e.pdf

16. Informatsiino-analitychni materialy shchodo stanu prodovolchoi bezpeky v Ukraini [Information and analytical materials about the state of food security in Ukraine]. Ofitsiinyi sait. Informatsiino-analitychnyi portal APK Ukrainy [Official site. Information and analytical portal of the AIC of Ukraine]. Available at: https://agro.me.gov.ua/storage/ app/sites/1/stanAPK_pdf_zvity/\%D0\%90\%D0\%9F\%D0\%9A\%202020/\%20\%D0\%B7\%D0\%B0\%202019\%20 \%D1\%80\%D1\%96\%D0\%BA_1.pdf (in Ukrainian)

17. Vytraty i resursy domohospodarstv Ukrainy u 2019 rotsi [Expenditures and resources of Ukrainian households in 2019]: Statystychnyi zbirnyk. Chastyna 1. Derzhavna sluzhba statystyky Ukrainy [Statistical collection. Part 1. State Statistics Service of Ukraine]. Kyiv, 2020. Available at: http://www.ukrstat.gov.ua/druk/publicat/kat_u/2020/ zb/06/zb_vrd_19_ue.pdf (in Ukrainian)

18. Ekspres-ohliad osnovnykh indykatoriv prodovolchoi bezpeky v Ukraini u 2019 rotsi [Express review of the main indicators of food security in Ukraine in 2019]. Ekonomichnyi dyskusiinyi klub [Economic discussion club]. Available at: http://edclub.com.ua/analityka/ekspres-oglyad-osnovnyh-indykatoriv-prodovolchoyi-bezpeky-v-ukrayini-u-2019-roci (in Ukrainian)

19. FAO (2020) The State of Food security and Nutrition in the World 2020. Prevalence of Undernourishment (PoU) projection tool. Available at: http://www.fao.org/publications/sofi/en/ 